\title{
DA EXIGÊNCIA DE LEI FORMAL E MATERIAL PARA CRIAÇÃO DE OBRIGAÇÕES ACESSÓRIAS COMO PRESSUPOSTO PARA APLICAÇÃO DE SANÇÃO
}

\author{
Rafael dos Santos Queiroz ${ }^{1}$ \\ Flávio Couto Bernardes ${ }^{2}$
}

\section{RESUMO}

O cumprimento das obrigações acessórias é imposto mediante normas de conduta. A estrutura normativa revela na hipótese a descrição do fato jurígeno, com os mesmos aspectos aplicáveis às normas que criam os tributos. A prescrição deve descrever a prestação e o modo de sua execução. As regras que irão compor essas normas devem ser inseridas no ordenamento por lei formal e material, em respeito à legalidade, proporcionando o fechamento do sistema jurídico. A norma de sanção tem por antecedente o descumprimento da norma de conduta. Há comando expresso no Código Tributário Nacional impondo sua criação por lei em sentido estrito.

Palavras-chave: Obrigação acessória. Norma de conduta. Legalidade. Norma sancionatória. Estado Democrático de Direito.

\section{THE CREATION OF INSTRUMENTAL OBLIGATIONS BY LAW AS REQUIREMENT FOR THE APPLICATION OF PENALTIES}

\begin{abstract}
The fulfillment of instrumental obligations is imposed by rules of conduct. The normative structure reveals the description of the legal fact, with the same aspects applicable to rules that create taxes. The legal text should describe the obligation and the manner of its execution. The rules that will make these standards should be included in legal system by formal and material law, in respect for the Constitution, providing the closure of legal system. The penalty is to antecedent breach of the rule of conduct. The command expressed in the National Tax Code imposes its creation by law in strict sense.
\end{abstract}

Keywords: Instrumental obligations. Rules of conduct. Legality. Rule of law. Taxes.

\footnotetext{
${ }^{1}$ Doutorando e Mestre em Direito pela PUC-MG, professor, advogado e conselheiro do Conselho Administrativo de Recursos Tributários do município de Belo Horizonte.

2 Doutor e Mestre em Direito pela UFMG, professor na UFMG e PUC-MG, advogado, procurador do município de Belo Horizonte.
}

Rev. de Direito Tributário e Financeiro | e-ISSN: 2526-0138 | Brasília | v. 3 | n. 1 | p. 140-159 | Jan/Jun. 2017 


\section{INTRODUÇÃO}

Pretende-se tratar da necessidade de respeito à legalidade para a imposição de obrigações acessórias aos contribuintes, como fundamento da aplicação de sanções pelo seu descumprimento.

A abordagem terá por essência a teoria normativa, discutindo-se a natureza da norma que cria a chamada obrigação acessória, bem como sua estrutura, justificando a necessidade de lei em sentido estrito.

Definidos os contornos da norma primária, tratar-se-á da norma de sanção vinculada a seu descumprimento e sua legitimidade.

\section{DAS OBRIGAÇÕES ACESSÓRIAS - IMPRECISÃO TERMINOLÓGICA}

O Código Tributário Nacional divide as obrigações tributárias entre principais e acessórias. Denomina-se obrigação principal aquela que tem por objeto o pagamento de tributo. Por acessória, toma-se aquela que determina ao sujeito passivo prestações positivas ou negativas, sempre no interesse da arrecadação ou fiscalização de tributos.

A denominação 'obrigação acessória' recebe críticas da doutrina, que defende se tratar de imprecisão terminológica imperdoável. A crítica abrange tanto o termo ‘obrigação', quanto 'acessória', por motivos que serão discutidos.

Quanto à caracterização de obrigação, defende-se ser incompatível com a definição do direito privado, no sentido de que o conceito se restringe às relações de caráter patrimonial.

Cumpre expor a crítica de Paulo de Barros Carvalho:

Tais relações são conhecidas pela designação imprecisa de obrigaçães acessórias,
nome impróprio, uma vez que não apresentam o elemento caracterizador dos laços
obrigacionais, inexistindo nelas prestação passível de transformação em termos
pecuniários. São liames concebidos para produzirem o aparecimento de deveres
jurídicos, que os súditos do Estado hão de observar, no sentido de imprimir efeitos
práticos à percepção dos tributos. É dever de todos prestar informações ao Poder
Público, executando certos atos e tomando determinadas providências de interesse
geral, para que a disciplina do relacionamento comunitário e a administração da ordem
pública ganhem dimensões reais concretas. Nessa direção, o cumprimento de
incontáveis deveres é exigido de todas as pessoas, no plano sanitário, urbanístico,
agrário, de trânsito etc., e, também, no que entende com a atividade tributante que o
Estado exerce. (CARVALHO, 2012, p. 281-2)

No mesmo sentido, especificando a falta de conteúdo patrimonial, conclui Luiz Eduardo Schoueri:

Rev. de Direito Tributário e Financeiro | e-ISSN: 2526-0138 | Brasília | v. 3 | n. 1 | p. 140 - 159 | Jan/Jun. 2017 
No caso das "obrigações acessórias", não é assim que ocorre. Se o contribuinte deixa, por exemplo, de preencher sua declaração de rendimentos, estará ele, por certo, sujeito a uma punição (multa). Esta não tem o caráter de indenizar o Estado pela falta da informação. Nada há de reparação. É mera penalidade imposta a quem não cumpriu seu dever. (SCHOUERI, 2012, p. 583)

Quanto ao termo 'acessória', o teor das críticas não é menos intenso. É fato que não há subordinação entre a obrigação principal e a acessória, que podem existir independentemente uma da outra, acarretando, inclusive, consequências distintas no caso de descumprimento. Sobre a acessoriedade, disserta Tércio Sampaio Ferraz Junior, citado por Schoueri:

\begin{abstract}
Sua acessoriedade não tem, como à primeira vista poderia parecer, o sentido de ligação a uma específica obrigação principal, da qual dependa. Na verdade, ela subsiste ainda quando a principal (à qual se liga ou parece ligar-se) seja inexistente em face de alguma imunidade ou não incidência. A marca de sua acessoriedade está, antes, na instrumentalidade para controle de cumprimento, sendo, pois, uma imposição de fazer ou não fazer de caráter finalístico. E, em face desse caráter, sujeitase à relação meio/fim, o que é nuclear, isto sim, para o exame da sua consistência jurídica. (FERRAZ, 2005, p. 268)
\end{abstract}

Em decorrência das imprecisões terminológicas expostas, propõe Carvalho a utilização da expressão 'deveres instrumentais', o que traria, sem dúvida, maior precisão ao texto legal.

Embora valorosa a discussão, como defende José Souto Maior Borges (1999), poderia o direito positivo denominar 'obrigação acessória' a relação jurídica existente para o Direito Tributário, de modo diverso daquele utilizado no Direito Privado. Dessa forma, a discussão não passaria de questão meramente terminológica.

Questão mais relevante para este estudo é a definição do fato gerador da obrigação acessória, como se passa a tratar.

\title{
3 DO FATO GERADOR DA OBRIGAÇÃO ACESSÓRIA - ESTRUTURA DA NORMA
}

O Código Tributário Nacional, em seu artigo 115, determina que o "Fato gerador da obrigação acessória é qualquer situação que, na forma da legislação aplicável, impõe a prática ou a abstenção de ato que não configure obrigação principal”.

$\mathrm{O}$ fato gerador, equivalente à expressão tatbestand, do direito alemão, é conceituado por Misabel de Abreu Machado Derzi (2007, p. 69), como “conceito que delimita rigidamente a espécie, à qual serão atribuídas consequências também específicas”. 
Há severas críticas na doutrina sobre a ocorrência ou não de fato gerador desencadeador da obrigação acessória. Defende-se que se trata de mero dever do sujeito passivo, decorrente de prescrições imperativas. É o que entende Sacha Calmon Navarro Coêlho:

\begin{abstract}
Vimos que as chamadas obrigações acessórias não possuem "fato gerador", decorrem de prescrições legislativas imperativas: "emita notas fiscais", "declare rendas e bens" e etc. A impropriedade redacional é sem par. Diz-se que o fato gerador da obrigação acessória é "qualquer situação" que, na forma de "legislação aplicável", impõe a "prática ou abstenção de ato". Outra maneira de prescrever deveres de fazer ou não fazer por força de lei. (COÊLHO, 2003, p. 369)
\end{abstract}

Ainda que crítica, a visão de Schoueri chega a admitir a existência do fato gerador:

É certo que muitas vezes a legislação, de fato, preverá uma hipótese abstrata que, uma vez concretizada, dará azo à "obrigação acessória"; a entrega de uma declaração de ajustes anual, no Imposto de Renda, é um exemplo. Entretanto, como se viu anteriormente, boa parte dos deveres instrumentais é contínua. A menos que se considere cada solicitação da autoridade fiscal (norma individual e concreta) um "fato gerador", não fará sentido o dispositivo do artigo 115 acima. (SCHOUERI, 2012, p. 586)

Discorda-se, entretanto, da afirmação de Coêlho e de Schoueri, no sentido de que as obrigações acessórias não teriam um fato gerador. Analisando a norma que cria esse dever, é de se concluir que se trata efetivamente de um juízo hipotético.

\title{
3.1 Da norma que cria a obrigação acessória
}

Não há dúvidas de que as obrigações acessórias são criadas através de normas de conduta. Segundo a classificação de Kelsen, não se pode admitir que se trate de juízos categóricos, logo, se organizam de forma hipotética. A norma que cria a obrigação acessória merece exame mais detido.

As normas jurídicas tributárias têm estrutura dual, dividindo-se em norma de conduta ou endonorma, e norma de sanção ou perinorma, conforme terminologia de Carlos Cossio e adotada por Coêlho (2000).

O dever de pagar tributo ou de cumprir prestações positivas ou negativas no interesse da fiscalização, está contido na endonorma, ficando a cargo da perinorma a sanção pelo seu descumprimento. Utilizar-se-á, para fins de distinção, a denominação norma tributária e norma instrumental. 


\title{
DA EXIGÊNCIA DE LEI FORMAL E MATERIAL PARA CRIAÇÃO DE OBRIGAÇÕES ACESSÓRIAS COMO PRESSUPOSTO PARA APLICAÇÃO DE SANÇÃO
}

As normas de conduta são conceituadas por Coêlho, em trecho que merece ser transcrito por sua clareza e abrangência:

\begin{abstract}
São as normas que obrigam comportamentos, campo de eleição da lógica jurídica. Destinam-se às autoridades e aos particulares. Desse tipo são as normas que estatuem comportamentos positivos ou negativos, desde que ocorrentes certos pressupostos. São nucleares, no sentido de posicionar à sua volta o sistema jurídico. Se o direito teleologicamente busca o controle do meio social, é claro que indica quais são os comportamentos desejáveis. Indica-os, tornando-os obrigatórios, como no caso do dever tributário. As leis preveem a obrigatoriedade de seu cumprimento. Todavia dita obrigatoriedade comportamental pode não ser expressa na lei. No caso do tributo, é. No caso do homicídio não. A lei expressa apenas uma punição, ou melhor, a previsão de uma pena para o comportamento homicida. A norma que impõe o dever de não matar é implícita no sistema e portanto inexpressa na lei (mais uma vez a diferença entre norma e lei). As normas-de-conduta ora impõem comportamentos positivos (é obrigatório pagar imposto de renda à União) ora estatuem condutas negativas (é obrigatório não matar). Fácil deduzir que o caráter proibido é epifenomênico; se é obrigatório não matar, matar é proibido. (COÊLHO, 2000, p. 78-9)
\end{abstract}

A endonorma, por sua vez, é composta pelo que Coêlho chama de hipótese de incidência, responsável pela descrição dos fatos jurígenos, e da consequência jurídica, que conterá a prescrição.

Cumpre tratar, a princípio da hipótese de incidência, tomando-se por exemplo a endonorma da norma jurídica tributária.

O antecedente da norma é, na teoria de Coêlho (2000), composta por quatro aspectos, quais sejam: a) material, representado pelo fato em si, em geral um ter, ser ou fazer; $b$ ) temporal, determinando o momento da ocorrência do fato; c) espacial, delimitando as coordenadas territoriais ligadas ao fato; e $d$ ) pessoal, ao qual se de dedica maior atenção.

Passando ao consequente da norma, superando a teoria de Paulo de Barros Carvalho, que trata simplesmente dos critérios pessoal e quantitativo, Coêlho traz os seguintes fatores: $a$ ) a quem pagar (sujeito ativo); b) quem deve pagar (sujeito passivo); c) quanto pagar (base de cálculo e alíquotas, adições e subtrações); d) como pagar; e) quando pagar; e $f$ ) onde pagar.

Não há como estruturar de forma diversa a endonorma da norma jurídica instrumental que cria a obrigação acessória. A estrutura de hipótese e consequência, tão somente contará com aspectos distintos da norma tributária.

Embora a doutrina também critique a expressão fato gerador, defendendo não existir um que faça nascer as obrigações acessórias, defende-se que há uma norma de conduta, cuja hipótese deve ser estudada. A nomenclatura ideal pode ser diversa da expressão fato gerador. Minúcias terminológicas, como já se observa, não são o escopo deste trabalho. 
Expostas as críticas, dedica-se a pensar a estrutura normativa da obrigação acessória. Carvalho, sob o ponto de vista normativo, afirma ser indiferente a denominação de hipótese, antecedente, suposto, antessuposto ou pressuposto. Importa a função que exerce na norma jurídica. A saber:

Há de significar, sempre, a descrição normativa de um evento que, concretizado no nível das realidades materiais e relatado no antecedente de norma individual e concreta, fará irromper o vínculo abstrato que o legislador estipulou na consequência. (CARVALHO, 2012, p. 247)

O antecedente da endonorma que cria a obrigação acessória deve ser estruturada com os mesmos aspectos presentes naquela que cria o dever de pagar o tributo, quais sejam, aspecto material, temporal, espacial e pessoal.

\subsection{Da estrutura da hipótese da endonorma}

\subsubsection{Aspecto material}

Como aspecto material, adota-se, como ponto de partida, o conceito de Carvalho:

Dessa abstração emerge o encontro de expressões genéricas designativas de
comportamentos de pessoas, sejam aqueles que encerram um fazer, um dar ou,
simplesmente, um ser (estado). Teremos, por exemplo, "vender mercadorias",
"industrializar produtos", "ser proprietário de bem imóvel", "auferir rendas",
"pavimentar ruas" etc.

Esse núcleo, ao qual nos referimos, será formado, invariavelmente, por um verbo, seguido de seu complemento. Daí porque aludirmos a comportamento humano, tomada a expressão na plenitude de sua força significativa, equivale a dizer, abrangendo não só as atividades refletidas (verbos que exprimem ação) como aquelas espontâneas (verbos de estado: ser, estar, permanecer etc.).

Com efeito, a afirmação de Coêlho de que as obrigações acessórias decorrem de prescrições legislativas imperativas é muito simplista. Só está obrigado ao cumprimento dos deveres constantes do direito posto aqueles que cumprirem a hipótese da norma.

O aspecto material, no caso da obrigação acessória, como descrito por Carvalho, importa no exercício de alguma conduta pelo sujeito passivo, expressa como fazer, dar ou ser.

Tomando-se por exemplo a declaração de serviços, como suporte da exigência do Imposto sobre Serviços, só pode ser imposta aos que prestem serviço (fazer) ou, ainda que não prestem, sejam prestadores ou tomadores de serviço (ser).

Rev. de Direito Tributário e Financeiro | e-ISSN: 2526-0138 | Brasília | v. 3 | n. 1 | p. 140 - 159 | Jan/Jun. 2017 


\section{DA EXIGÊNCIA DE LEI FORMAL E MATERIAL PARA CRIAÇÃO DE OBRIGAÇÕES ACESSÓRIAS COMO PRESSUPOSTO PARA APLICAÇÃO DE SANÇÃO}

O mesmo raciocínio se aplica à obrigação de emissão de notas fiscais. Necessário que se tenha prestado um serviço ou vendido um determinado produto. $\mathrm{O}$ mesmo se pode dizer em relação à obrigação negativa de não manter em estoque mercadoria desacobertada de nota fiscal. Exige-se do sujeito passivo ao menos a condição de contribuinte do imposto, mesmo que não tenha cumprido o dever de se inscrever no órgão fazendário.

O dever de prestar informações ao Fisco também é subordinado a esta condição de ser ou fazer, sem a qual não se observaria o requisito de ser o fato de interesse da fiscalização ou arrecadação de tributos.

Frise-se que, como já discutido, o aspecto material que ora se constrói não é vinculado ao da norma que cria o dever de pagar o tributo. Essa dissociação pode ser observada quando do exame, por exemplo, do dever de transmitir a declaração de papel imune, nos casos de edição de livros, que persiste ainda que não haja imposto devido.

\subsubsection{Aspecto espacial}

Trata-se do local em que o legislador determina a ocorrência do fato jurídico. Assim como ocorre na norma tributária, que determina o pagamento do tributo para determinado ente em virtude da ocorrência do fato jurídico naquele local, a norma instrumental determinará o ente competente para exigir a prestação.

Na lição de Carvalho, o aspecto espacial segue a seguinte classificação, que, como ora se defende, estender-se-ia integralmente à norma instrumental:

\footnotetext{
Acreditamos que os elementos indicadores da condição de espaço, nos supostos das normas tributárias, hão de guardar uma dessas três formas compositivas, diretriz que nos conduz a classificar o gênero tributo na conformidade do grau de elaboração do critério espacial da respectiva hipótese tributária:

a) hipótese cujo critério espacial faz menção a determinado local para a ocorrência do fato típico;

b) hipótese em que o critério espacial alude a áreas específicas, de tal sorte que o acontecimento apenas ocorrerá se dentro delas estiver geograficamente contido;

c) hipótese de critério espacial bem genérico, onde todo e qualquer fato, que suceda sob o manto da vigência territorial da lei instituidora, estará apto a desencadear seus efeitos peculiares. (CARVALHO, 2012, p. 256)
}

Como exemplo, a declaração do ICMS será devida ao Estado em que se estabelecer o contribuinte. O cadastro do imóvel será realizado na prefeitura do Município em que situar. 
Discute-se, inclusive, a legitimidade dos Municípios que exigem cadastro de contribuintes que ali não têm estabelecimento. Entretanto, havendo vínculo com aquele local, visto que presta serviços a tomadores ali localizados, haveria interesse daquele sujeito ativo na arrecadação ou fiscalização de tributos.

\subsubsection{Aspecto temporal}

$\mathrm{O}$ aspecto temporal tem por finalidade definir o momento em que se considera ocorrido o fato descrito no critério material. Referindo-se à norma tributária, seguindo a metodologia até aqui aplicada, afirma Carvalho:

Compreendemos o critério temporal da hipótese tributária como o grupo de indicações, contidas no suposto da regra, e que nos oferecem elementos para saber, com exatidão, em que preciso instante acontece o fato descrito, passando a existir o liame jurídico que amarra devedor e credor, em função de um objeto - o pagamento de certa prestação pecuniária. (CARVALHO, 2012, p. 260)

Mais uma vez, não há distinção quanto à aplicação deste critério à norma instrumental. Da mesma forma, o ordenamento deve designar o momento em que se considera ocorrido seu fato gerador.

O raciocínio se aplica mesmo à hipótese proposta por Schoueri, em citação anterior, que defendia que não haveria fato gerador por terem as obrigações acessórias, muitas vezes, caráter contínuo, a menos que se considerasse cada solicitação de informações do sujeito ativo como um fato gerador.

Plausível a formulação. Com efeito, na obrigação de prestar esclarecimentos ao Fisco, somente se implementaria o aspecto temporal quando da intimação, sendo que poderia ocorrer quantas vezes se fizesse necessário.

\subsubsection{Aspecto pessoal}

Fugindo à doutrina de Carvalho, adota-se a estrutura proposta por Coêlho, acrescentando-se na hipótese o aspecto pessoal, que assim se justifica:

Isto posto, ao lado dos aspectos material, temporal e espacial, acrescentamos ao fato jurígeno, na hipótese da endonorma, um aspecto pessoal. É que o fato jurígeno (um "ser", "ter", "estar" ou “fazer") está sempre ligado a uma pessoa e, às vezes, os tributos 


\section{DA EXIGÊNCIA DE LEI FORMAL E MATERIAL PARA CRIAÇÃO DE OBRIGAÇÕES ACESSÓRIAS COMO PRESSUPOSTO PARA APLICAÇÃO DE SANÇÃO}

ou qualificações dessa pessoa são importantes para a delimitação da hipótese de incidência. (COELHO, 2000, p. 113)

Nas normas instrumentais também se faz imprescindível o aspecto pessoal, por definir as características da pessoa que deve qualificar o fato jurígeno, fazendo nascer a relação jurídica.

Tomando por exemplo a venda de um veículo, caso a pessoa que pratique o ato seja comerciante desse segmento, deverá emitir nota fiscal, prestar declaração sobre a venda e registrar a operação em sua escrita contábil. A pessoa física que realiza a mesma operação não está sujeita a essas obrigações.

Como resta demonstrado, há fato gerador da obrigação acessória, estruturada com os mesmos aspectos da norma tributária. Implementada a hipótese da endonorma, o ordenamento deverá atribuir a respectiva consequência.

\subsection{Do consequente da endonorma}

O consequente da norma jurídica contém a prescrição da conduta desejada pelo legislador, inserida no ordenamento jurídico conforme critérios políticos. Descreve a prestação que poderá ser exigida do sujeito passivo que praticou o fato descrito na hipótese.

Sobre o consequente da norma disserta Carvalho:

\footnotetext{
Se a hipótese, funcionando como descritor, anuncia os critérios conceptuais para o reconhecimento de um fato, o consequente, como prescritor, nos dá, também, critérios para a identificação do vínculo jurídico que nasce, facultando-nos saber quem é o sujeito portador do direito subjetivo; a quem foi cometido o dever jurídico de cumprir certa prestação; e seu objeto, vale dizer, o comportamento que a ordem jurídica espera do sujeito passivo e que satisfaz, a um só tempo, o dever que lhe fora atribuído e o direito subjetivo de que era titular o sujeito pretensor.
}

Ao preceituar a conduta, fazendo irromper direitos subjetivos e deveres jurídicos correlatos, o consequente normativo desenha a previsão de uma relação jurídica, que se instala, automática e infalivelmente, assim que se concretize o fato. (CARVALHO, 2012, p. 276)

Carvalho (2012), em sua estrutura da endonorma tributária, insere no consequente os aspectos pessoal e quantitativo. $\mathrm{O}$ aspecto pessoal, refere-se aos sujeitos ativo e passivo. No aspecto quantitativo, trata da base de cálculo e da alíquota.

Coêlho (2000), especifica sua estrutura debatendo a quem pagar, quem deve pagar, quanto pagar, como pagar e onde pagar.

Rev. de Direito Tributário e Financeiro | e-ISSN: 2526-0138 | Brasília | v. 3 | n. 1 | p. 140 - 159 | Jan/Jun. 2017 
Adotando a estrutura detalhada, no caso da norma instrumental deve-se perguntar quem deve prestar, a quem deve prestar, como deve prestar, quando deve prestar e onde deve prestar.

Todos esses aspectos se aplicam perfeitamente às obrigações acessórias, delimitando a relação jurídica que passa a existir entre as partes.

\section{DA RELAÇÃO JURÍDICA INSTRUMENTAL - OBRIGAÇÃO ACESSÓRIA}

Acerca das críticas já colacionadas à expressão obrigação, defendendo que a obrigação acessória não teria caráter patrimonial, acredita-se ser simples questão terminológica. Importa para este estudo o nascimento da relação jurídica, decorrente do implemento da conduta descrita na hipótese da endonorma.

A relação jurídica escapa ao estreito conceito de obrigação. Carvalho a conceitua como a seguir transcrito:

Para a Teoria Geral do Direito, relação jurídica é definida como o vínculo abstrato, segundo o qual, por força da imputação normativa, uma pessoa, chamada de sujeito ativo, tem o direito subjetivo de exigir de outra, denominada sujeito passivo, o cumprimento de certa prestação. (CARVALHO, 2012, p. 277)

Em respeito à segurança jurídica, o consequente da norma deve ser fixado por lei, respeitadas as garantias constitucionais, no sentido de ser necessário que o agente tenha ciência e previsibilidade dos efeitos de sua conduta. $O$ vínculo entre a hipótese e a consequência se dá pela interpretação lógica da norma. Assim conclui Carvalho:

\footnotetext{
A hipótese normativa está ligada à consequência pelo elo da imputação deôntica, fixado ao talante do político, no tempo da elaboração da lei. O vínculo implicacional que se estabelece no consequente - a relação jurídica — diferentemente, é regido pelas leis lógicas. Enquanto a primeira implicação é posta pelo sistema normativo, que livremente a constitui e desconstitui, a segunda decorre de imposições lógicas ante as quais o sistema não escapa. (CARVALHO, 2012, p. 278)
}

Corroborando a conclusão de Carvalho, Coêlho (2000, p. 92) afirma que lei é um ente positivo enquanto norma é um ser lógico. Defende que o que incide não é a lei, mas o preceito da norma, quando implementada sua hipótese.

Muito importante para a segurança jurídica e para o sistema tributário, ainda mais que a discussão terminológica, é a expressão 'legislação tributária', de que decorreriam as obrigações acessórias, conforme artigo 113, do Código Tributário Nacional. 


\section{DA EXIGÊNCIA DE LEI FORMAL E MATERIAL PARA CRIAÇÃO DE OBRIGAÇÕES ACESSÓRIAS COMO PRESSUPOSTO PARA APLICAÇÃO DE SANÇÃO}

O artigo 96, afirma que "a expressão "legislação tributária" compreende as leis, os tratados e as convenções internacionais, os decretos e as normas complementares que versem, no todo ou em parte, sobre tributos e relações jurídicas a eles pertinentes".

Em interpretação sistemática, envolvendo a Constituição como fundamento de validade das demais regras, a obrigação acessória deve ser criada por lei, em sentido estrito, por impor ao particular uma conduta determinada. Há que ser respeitada a legalidade proposta pelo artigo $5^{\circ}$, inciso II, da Constituição Federal.

A exigência de lei é fundamento do sistema jurídico autopoiético, que somente admite a interferência política cumpridos os critérios do acoplamento estrutural proposto por Luhmann.

\section{DO FUNDAMENTO DA LEGALIDADE}

Conforme relata Heleno Taveira Torres (2011, p. 152), no início do século XX, Kelsen defendeu a coincidência entre o Direito e o Estado. Surgia a teoria do 'Estado Constitucional de Direito', tendo a Constituição a função de definir a estrutura do Estado, hierarquizar os níveis normativos e, dentro do sistema jurídico, servir de fundamento de validade das normas jurídicas.

Opera-se, com a promulgação da Constituição, resultado da vontade política, a transferência da soberania do povo para o direito. Necessário transcrever a conclusão Torres sobre o tema:

\footnotetext{
Com a promulgação do texto constitucional, a soberania transfere-se do povo à Constituição, na forma de competências. A partir daí, a soberania passa a ser o conteúdo da competência dos órgãos do Estado por ela criados, com regência material plena sobre todo o ordenamento e, por conseguinte, sobre todo o Estado. (TORRES, 2011, p. 156)
}

Tendo a Constituição como fundamento de validade das normas que vierem a ser produzidas, todas as decisões políticas passam a ser controladas pelo direito. Como enuncia Marcelo Neves (2006, p. 96), “a Constituição deve ser apreendida como uma limitação jurídica ao governo, a antítese do regime arbitrário".

A Constituição proporciona, portanto, a existência de dois sistemas fechados, o jurídico e o político. Embora operacionalmente autônomos, os sistemas mantém uma interdependência, explicitada nas palavras de Marcelo Neves (2006, p. 89), que afirma que "Assim como as 
decisões políticas subordinam-se ao controle jurídico, o direito positivo não pode prescindir, por exemplo, de legislação consolidada e deliberada politicamente”.

Essa interdependência fundamentada na Constituição é denominada por Luhmann de acoplamento estrutural. Embora os sistemas sejam autopoiéticos ou operacionalmente fechados, tratando especialmente, do sistema jurídico, a existência de uma abertura cognitiva é condição de sua própria viabilidade.

Cabe ao ambiente, aqui representado pelo sistema político, alimentar o sistema jurídico, gerando o input de normas aprovadas pelo legislador, tendo sua validade condicionada ao atendimento dos controles jurídicos de procedimento e conteúdo. Sobre a abertura discorre Derzi:

\begin{abstract}
A abertura para o real possibilita o aperfeiçoamento da ordem positiva, através das correções feitas pelo legislador nas leis que alimentam o sistema; igualmente, viabiliza as mudanças nos conceitos socialmente mais adequados e, com isso, alteramse os resultados das operações internas, inclusive da autoridade jurisdicional, que podem ser medidos, no output do sistema. (DERZI, 2009, p. 31)
\end{abstract}

A Constituição assume papel imprescindível na limitação da produção normativa, impondo ao sistema político rígido controle do processo legislativo. Marcelo Neves (2006, p. 151) afirma que o Estado Democrático de Direito realiza a intermediação entre o consenso procedimental e o dissenso conteudístico. Aduz que o simples consenso acerca do procedimento como legitimador de qualquer norma produzida, poderia levar a uma ditadura. Dessa forma, deve haver controle jurídico do conteúdo das normas, com fundamento na Constituição. A importância do direito constitucional no sistema jurídico é destacada por Marcelo Neves:

O direito constitucional funciona - pode-se afirmar do ponto de vista jurídicosociológico - como limite sistêmico-interno para a capacidade de aprendizado (abertura cognitiva) do direito positivo; em outras palavras: a Constituição determina até que ponto o sistema jurídico pode reciclar-se sem perder sua autonomia operacional. (NEVES, 2013, p. 71)

Resulta desse acoplamento, regido por regras próprias, um sistema jurídico autodeterminado, fundamentado na positividade. A vinculação de todo o sistema à norma jurídica exclui do processo decisório qualquer influência do ambiente.

Opta-se, nesse raciocínio, devido à necessidade de se manter o sistema jurídico autopoiético, pelo positivismo jurídico exclusivo, eliminando do processo decisório referências alheias ao ordenamento. Ao contrário do que se propaga, o positivismo não paralisa o direito, 


\section{DA EXIGÊNCIA DE LEI FORMAL E MATERIAL PARA CRIAÇÃO DE OBRIGAÇÕES ACESSÓRIAS COMO PRESSUPOSTO PARA APLICAÇÃO DE SANÇÃO}

impossibilitando a sua modernização pela interpretação. Interpreta-se conforme os valores vigentes na sociedade ao tempo da sua aplicação, como descrito nas palavras de Torres:

No positivismo jurídico exclusivo - PJE, os valores são integrados à interpretação das normas jurídicas (regras e princípios), sem qualquer recurso ao exterior do ordenamento. A norma é posta, como assinala Joseph Raz, segundo as regras secundárias ou de reconhecimento, por uma fonte autorizada (strong social thesis), e os valores inspiradores da norma ou mesmo da autoridade (única fonte do direito para Raz) não acompanham a vida dessa norma jurídica, tarefa que passa à interpretação, a cada ato de aplicação segundo os valores de seu momento. (TORRES, 2011, p. 56)

A Constituição deve substituir os elementos externos ao sistema jurídico, tais como a política, a moral, a economia e todos os demais, servindo como parâmetro de modernização conforme os anseios da sociedade, limitando-se, porém ao seu texto. É o que afirma Marcelo Neves:

\footnotetext{
A Constituição deve, com outras palavras, substituir apoios externos, tais como os que foram postulados pelo direito natural. Ela impede que critérios externos de natureza valorativa, moral e política, tenham validade imediata no interior do sistema jurídico, delimitando-lhe, dessa maneira, as fronteiras. (NEVES, 2006, p. 99)
}

Admitir a competência do Poder Executivo para criar, via norma de conduta, as obrigações acessórias, é entregar ao sistema político o poder de criar condutas exigíveis, em prejuízo da legalidade.

\section{DA INCONSTITUCIONALIDADE DA DELEGAÇÃO AO EXECUTIVO DA COMPETÊNCIA PARA IMPOR OBRIGAÇÕES ACESSÓRIAS}

Partindo da premissa de que somente pode integrar o sistema jurídico a regra que cumprir os controles formais e de conteúdo previstos na Constituição, não se pode admitir que simples delegação genérica ao Poder Executivo seja suficiente para satisfazer o princípio da legalidade.

No que se refere às obrigações acessórias, é o que se observa no cenário atual. Como exemplo, toma-se o disposto no artigo 17, da Lei $\mathrm{n}^{\circ}$ 9.779/99:

Art. 16. Compete à Secretaria da Receita Federal dispor sobre as obrigações acessórias relativas aos impostos e contribuições por ela administrados, estabelecendo, inclusive, forma, prazo e condições para o seu cumprimento e o respectivo responsável. 
Trata-se de autêntica norma de competência que, ainda que em desacordo com a Constituição Federal, delega poderes ilimitados ao Executivo, para impor condutas aos contribuintes.

Com fundamento na delegação recebida, a Secretaria da Receita Federal do Brasil criou e disciplinou a Declaração de Débitos e Créditos Tributários Federais (DCTF), por meio da Instrução Normativa RFB n 1.110, de 24 de dezembro de 2010.

A referida Instrução Normativa dispõe sobre todos os aspectos da norma instrumental, conforme estruturada neste trabalho.

Além de se inserir no ordenamento toda a endonorma instrumental em flagrante desrespeito à legalidade, o seu descumprimento constitui a hipótese da perinorma.

\title{
7 DA NORMA DE SANÇÃO
}

Afirma Carvalho (2002, p. 31), que "a natureza do Direito é instrumental e a essência desse instrumento é a coatividade que se exerce mediante a possibilidade de constrangimento físico ou de execução forçada".

A sanção é essencial ao sistema jurídico, visto que confere efetividade à norma de conduta positivada, exercendo, segundo Coimbra (2007, p. 60), as funções preventiva, repressiva, reparatória, didática e assecuratória. Não houvesse a sanção, dificilmente seria obtida a observância da norma, mesmo que possa ser imposta ao cidadão.

A estrutura da norma sancionatória tem em sua hipótese a descrição do fato ilícito, qual seja, o descumprimento da norma de conduta. É o que afirma Carvalho:

\begin{abstract}
O suposto das regras sancionatórias, como já vimos, hospeda sempre a descrição de um acontecimento do mundo físico exterior, no qual alguém deixou de cumprir determinada prestação a que estava submetido, por força de outra norma jurídica de conduta. Tratando-se de matéria tributária, o ilícito pode advir da não prestação do tributo (da importância pecuniária), ou do não cumprimento de deveres instrumentais ou formais. Seja como for, haverá um constante e invariável traço que identifica, prontamente, estarmos diante de uma hipótese de ilícito tributário: é a não prestação (não p), presente onde houver fórmula descritiva de infração. (CARVALHO, 2012, p. 450)
\end{abstract}

O consequente da norma sancionatória prescreverá a penalidade inserida no ordenamento, conforme vontade do legislador:

Atrelada ao antecedente ou suposto da norma sancionadora está a relação deôntica, vinculando, abstratamente, o autor da conduta ilícita ao titular do direito violado. No 


\title{
DA EXIGÊNCIA DE LEI FORMAL E MATERIAL PARA CRIAÇÃO DE OBRIGAÇÕES ACESSÓRIAS COMO PRESSUPOSTO PARA APLICAÇÃO DE SANÇÃO
}

\begin{abstract}
caso das penalidades pecuniárias ou multas fiscais, o liame também é de natureza obrigacional, uma vez que tem substrato econômico, denomina-se relação jurídica sancionatória e o pagamento da quantia estabelecida é promovido a título de sanção. Tratando-se de outro tipo de sanção, que não é multa ou penalidade pecuniária, a relação não se altera na sua estrutura básica, modificando-se apenas o objetivo da prestação, que será um fazer ou não fazer. Perde o nome de vínculo de cunho obrigacional, mas continua sendo uma relação jurídica sancionatória. (CARVALHO, 2012, p. 449)
\end{abstract}

Observa-se que, em respeito ao artigo 97 do Código Tributário Nacional, ainda que a endonorma instrumental seja inserida no ordenamento por ato infralegal, o consequente da perinorma é sempre criada por lei.

$\mathrm{O}$ legislador se preocupa em atender explicitamente o disposto no inciso $\mathrm{V}$, do artigo 97, que determina que somente a lei pode estabelecer "a cominação de penalidades para as ações ou omissões contrárias a seus dispositivos, ou para outras infrações nela definidas”.

A interpretação da norma de competência que delega poderes ao Executivo é tão desconexa do sistema jurídico que chega ao absurdo de criar por lei apenas meia norma de sanção, impondo penalidade pelo descumprimento de uma conduta que não atende a legalidade.

Para tornar ainda mais impróprio o exemplo adotado, tão difundido na doutrina, a sanção pelo descumprimento das obrigações acessórias em âmbito federal são impostas genericamente por uma Medida Provisória, que nunca se submeteu ao crivo da legalidade.

Trata-se da Medida Provisória n ${ }^{\circ}$ 2.158-35, de 24 de agosto de 2001, em vigor até a presente data em razão do artigo $2^{\circ}$, da Emenda Constitucional $n^{\circ} 32$. Transcreve-se seu artigo 57:

Art. 57 - O sujeito passivo que deixar de cumprir as obrigações acessórias exigidas nos termos do art. 16 da Lei $n^{\circ}$ 9.779, de 19 de janeiro de 1999, ou que as cumprir com incorreções ou omissões será intimado para cumpri-las ou para prestar esclarecimentos relativos a elas nos prazos estipulados pela Secretaria da Receita Federal do Brasil e sujeitar-se-á às seguintes multas: (Redação dada pela Lei $\mathrm{n}^{\mathbf{o}}$ 12.873, de 24 de outubro de 2013)

I - por apresentação extemporânea:

a) $\mathrm{R} \$ 500,00$ (quinhentos reais) por mês-calendário ou fração, relativamente às pessoas jurídicas que estiverem em início de atividade ou que sejam imunes ou isentas ou que, na última declaração apresentada, tenham apurado lucro presumido ou pelo Simples Nacional; (Redação dada pela Lei n ${ }^{\circ} 12.873$, de 24 de outubro de 2013)

b) $\mathrm{R} \$ 1.500,00$ (mil e quinhentos reais) por mês-calendário ou fração, relativamente às demais pessoas jurídicas; (Redação dada pela Lei $n^{\circ} 12.873$, de 24 de outubro de 2013)

c) $\mathrm{R} \$ 100,00$ (cem reais) por mês-calendário ou fração, relativamente às pessoas físicas; (Incluído pela Lei no 12.873 , de 24 de outubro de 2013)

Rev. de Direito Tributário e Financeiro | e-ISSN: 2526-0138 | Brasília | v. 3 | n. 1 | p. 140 - 159 | Jan/Jun. 2017 
II - por não cumprimento à intimação da Secretaria da Receita Federal do Brasil para cumprir obrigação acessória ou para prestar esclarecimentos nos prazos estipulados pela autoridade fiscal: R \$ 500,00 (quinhentos reais) por mês-calendário; (Redação dada pela Lei $\mathrm{n}^{\circ} 12.873$, de 24 de outubro de 2013)

III - por cumprimento de obrigação acessória com informações inexatas, incompletas ou omitidas: (Redação dada pela Lei $\mathrm{n}^{\circ} 12.873$, de 24 de outubro de 2013)

a) $3 \%$ (três por cento), não inferior a $\mathrm{R} \$ 100,00$ (cem reais), do valor das transações comerciais ou das operações financeiras, próprias da pessoa jurídica ou de terceiros em relação aos quais seja responsável tributário, no caso de informação omitida, inexata ou incompleta; (Incluído pela Lei n 12.873, de 24 de outubro de 2013)

b) $1,5 \%$ (um inteiro e cinco décimos por cento), não inferior a $\mathrm{R} \$ 50,00$ (cinquenta reais), do valor das transações comerciais ou das operações financeiras, próprias da pessoa física ou de terceiros em relação aos quais seja responsável tributário, no caso de informação omitida, inexata ou incompleta. (Incluído pela Lei no 12.873 , de 24 de outubro de 2013)

A lei, ou o que deveria ser lei, conforme o Código Tributário Nacional, somente se ocupa da perinorma. A segurança jurídica reclama mais previsibilidade e respeito à legalidade, com a interpretação correta da Constituição Federal.

Importante salientar que tramita perante o Supremo Tribunal Federal a Ação Civil Originária n ${ }^{\circ} 1.098$ movida pelo Estado de Minas Gerais em face da União Federal, foi suscitada necessidade de lei formal para criação da DCTF, e via de consequência para a imposição de penalidade, já que o antecedente da norma de sanção é o descumprimento da norma de conduta.

Em divergência iniciada pelo Ministro Marco Aurélio Mello, foi concedida antecipação de tutela para suspender a exigibilidade da obrigação acessória, vencido o relator, Ministro Joaquim Barbosa. O referido acórdão tem a seguinte ementa:

OBRIGAÇÃO TRIBUTÁRIA ACESSÓRIA - SURGIMENTO POR FORÇA DE INSTRUÇÃO DA RECEITA FEDERAL - RELEVÂNCIA DO PEDIDO DE CONCESSÃO DE TUTELA ANTECIPADA E RISCO DE MANTER-SE O QUADRO COM PLENA EFICÁCIA. Ante o disposto no artigo 113, § 2 $2^{\circ}$ do Código Tributário Nacional, a exigir lei em sentido formal e material para ter-se o surgimento de obrigação tributária, ainda que acessória, mostra-se relevante pedido de tutela antecipada veiculado por Estado, visando a afastar sanções, considerado o que previsto em instrução da Receita Federal.

A decisão tem enorme importância, corroborando muitas outras proferidas no âmbito do Tribunal Regional Federal da $1^{\text {a }}$ Região, no sentido de exigir lei em sentido formal para a imposição de obrigação acessória. 
8 DA IMPOSSIBILIDADE DE IMPOSIÇÃO DE NORMA DE CONDUTA OU DE SANÇÃO EM DESRESPEITO Á LEGALIDADE - CONSLUSÃO

O Poder Executivo não tem competência normativa ilimitada. Antes, pelo contrário, deve exercê-la de forma restrita e se ater à sua função sistêmica. Torres (2011, p. 345), citando Vilanova, afirma que cada órgão é um "feixe de competência", com atribuições de criação ou aplicação do direito. Diz ainda:

\begin{abstract}
Somente aquelas regras expedidas por agentes previamente habilitados com título legítimo para produzir atos normativos (órgãos), segundo os critérios prévios de ação possível para o exercício de regulação de condutas (competências), e dês que agindo mediante um encadeamento de atos necessários (processo ou procedimento), podem receber a qualificação de "normas jurídicas" e, por conseguinte, desencadearem efeitos típicos de produção de deveres e direitos subjetivos, conferirem amparo jurídico aos interesses visados. (TORRES, 2011, p. 345-6)
\end{abstract}

O encadeamento de normas de competência deve se iniciar pela Constituição, fundamento de validade das demais normas, segundo a qual as demais devem ser interpretadas. Não é o que se observa da interpretação dada pelo Estado do artigo 113 , § $2^{\circ}$, do Código Tributário Nacional.

A inserção indevida de atos normativos do Executivo, sem o devido controle jurídico, denota a politização do direito, por falta de atuação dos órgãos competentes, dotados dos poderes necessários para exercê-lo. As garantias constitucionais se revelam meramente simbólicas, falhando em sua função de garantir a autopoiese do sistema jurídico. É o que afirma Marcelo Neves:

\footnotetext{
No caso de constitucionalização simbólica, a politização desdiferenciante do sistema jurídico não resulta do conteúdo dos próprios dispositivos constitucionais. Ao contrário, o texto constitucional proclama um modelo político-jurídico no qual estaria assegurada a autonomia operacional do direito. Mas do sentido em que se orientam a atividade constituinte e a concretização do texto constitucional resulta o bloqueio político da reprodução operacionalmente autônoma do sistema jurídico. (NEVES, 2013, p. 149)
}

A Constituição é estruturada de forma a garantir a autopoiese do sistema jurídico, exigindo respeito à legalidade para todos os ramos do direito, sujeitando à lei em sentido formal e material a imposição de qualquer conduta ao cidadão.

A legislação infraconstitucional, em desacordo com o texto constitucional, tenta evitar sua concretização, reclamando a intervenção do Poder Judiciário. A falta de concretização tornaria a Constituição meramente simbólica. 
Sobre o caráter simbólico da Constituição, hipertrofiada em relação a concessão de direitos e garantias, que, entretanto não são concretizadas, disserta Marcelo Neves:

Caso não seja construída normatividade constitucional suficiente durante o processo de concretização, de tal maneira que ao texto constitucional não corresponda estrutura normativa como conexão entre programa e âmbito normativos, a legislação ordinária como linguagem-objeto fica prejudicada em sua normatividade. (NEVES, 2013, p. 100-1)

A intervenção do Poder Judiciário se faz pertinente e necessária para conferir ao artigo 113, parágrafo $2^{\circ}$ do Código Tributário Nacional a correta interpretação, tornando imprescindível a criação das obrigações acessórias, em seus contornos essenciais, por lei em sentido formal e material.

Trata-se de ato inerente ao Estado Democrático de Direito, e deve ser implementado, dando efetividade ao comando constitucional e privilegiando o fechamento do sistema jurídico, contra a inserção política de normas de conduta.

A exigência de lei restauraria, ainda, a lógica do sistema normativo, que não pode admitir que somente o consequente da perinorma seja estabelecido por lei, enquanto a endonorma e o antecedente da perinorma, seu descumprimento, estejam sujeitos ao desejo autocrático do Poder Executivo.

\section{REFERÊNCIAS}

ÁVILA, Humberto. Segurança Jurídica: Entre Permanência, Mudança e Realização no Direito Tributário. São Paulo: Malheiros, 2011.

BORGES, José Souto Maior. Obrigação tributária - uma introdução metodológica. São Paulo: Malheiros, 1999.

BRASIL. União Federal. Lei n. 9.784, de 29 de janeiro de 1999 . In < http://www.planalto.gov.br/ccivil_03/leis/19784.htm> Acesso em 02 ago. 2014.

BRASIL. União Federal. Lei n. 11.941, de 27 de maio de 2009. In < http://www.planalto.gov.br/ccivil_03/_ato2007-2010/2009/lei/111941.htm> Acesso em 02 ago. 2014.

BRASIL. União Federal. Decreto n. 70.235, de 06 de março de 1972. In < http://www.planalto.gov.br/ccivil_03/decreto/D70235cons.htm> Acesso em 02 ago. 2014. 
BRASIL. União Federal. Constituição da República Federativa do Brasil, de 5 de outubro de

<http://www.planalto.gov.br/ccivil_03/Constituicao/Constituiçao_Compilado.htm> Acesso em 02 ago. 2014.

BRASIL. Câmara Superior de Recursos Fiscais. Recurso Especial n. 255.483. PIS Ressarcimento. Recorrente: Fazenda Nacional. Interessado: Doux Frangosul S/A - Agro Avícola Industrial. Relatora: Dra. Nanci Gama. In < file://C:/Users/Rafael\%20Queiroz/Downloads/Decisao_13053000211200672.pdf> Acesso em 02 ago. 2014.

CARVALHO, Paulo de Barros. Curso de Direito Tributário. São Paulo: Saraiva, 2012.

DANTAS, Rodrigo Numeriano Dubourq. Competência Regulamentar da Administração Tributária, Legalidade e Segurança Jurídica. In Revista Dialética de Direito Tributário, vol. 217, São Paulo, outubro, 2013.

DERZI, Misabel Abreu Machado. Direito Tributário, Direito Penal e Tipo. São Paulo: Revista dos Tribunais, 2007.

, Modificações da jurisprudência no Direito Tributário. São Paulo: Noeses, 2009.

DI PETRO, Maria Sylvia Zanella. Discricionariedade administrativa na Constituição de 1988. São Paulo: Atlas, 2007.

FERRAZ, Tercio Sampaio. Obrigação tributária acessória e limites de imposição. In Teoria geral da obrigação tributária. Estudos em homenagem ao Professor Souto Maior Borges. São Paulo: Malheiros, 2005.

FERREIRA, Edimur Ferreira de. Curso de direito administrativo positivo. Belo Horizonte: Del Rey, 2011.

MARINS, James. Direito Processual Tributário Brasileiro. São Paulo: Dialética, 2014.

MELlO, Celso Antônio Bandeira de. Curso de Direito Administrativo. São Paulo: Malheiros, 2009.

NEDER, Marcos Vinicius; LÓPEZ, Maria Teresa Martínez. Processo Administrativo Fiscal Federal Comentado. São Paulo: Dialética, 2010.

NEVES, Marcelo. Entre Têmis e Leviatã: Uma relação difícil. São Paulo: Martins Fontes, 2006.

A Constitucionalização Simbólica. São Paulo: Martins Fontes, 2013.

PAULSEN, Leandro. Segurança Jurídica, Certeza do Direito e Tributação. Porto Alegre: Livraria do Advogado, 2006.

Rev. de Direito Tributário e Financeiro | e-ISSN: 2526-0138 | Brasília | v. 3 | n. 1 | p. 140 - 159 | Jan/Jun. 2017 
PIZZOLIO, Reinaldo. Competência Tributária e Conceitos Constitucionais. São Paulo: Quartier Latin, 2006.

RIBEIRO, Ricardo Lodi. Os Conceitos Indeterminados no Direito Tributário. In Revista Dialética de Direito Tributário, vol. 149, São Paulo, fevereiro, 2008.

TÔRRES, Heleno Taveira. Direito Constitucional Tributário e Segurança Jurídica. São Paulo: Revista dos Tribunais, 2011.

XAVIER, Alberto. Tipicidade da Tributação, Simulação e Norma Antielisiva. São Paulo: Dialética, 2002. 